\title{
Beto Rockfeller, a Motocicleta e o Engov ${ }^{1}$
}

\author{
////////////I Esther Hamburger ${ }^{2}$
}

1. Texto produzido no interior do Projeto Fapesp Digitalização do Acervo da Tupi, por mim coordenado e desenvolvido em parceria com a Cinemateca Brasileira, que detém o referido acervo. O texto contou com a colaboração de Renata Keller.

2. Professora do PPG Meios e Processos Audiovisuais. E-mail: ehamb@ usp.br 
Resumo Baseado na análise dos sete capítulos da novela Beto Rockfeller (1968-9, Bráulio Pedroso), exibida e produzida pela TV Tupi de São Paulo, restaurados recentemente pela Cinemateca Brasileira com recursos de projeto FAPESP de digitalização de acervos, e em pesquisa em arquivos publicados na imprensa especializada da época, esse artigo discute as maneiras concretas pelas quais o título conhecido por ter introduzido gravações em locação, diálogos coloquiais, figurinos inovadores, em narrativas contemporâneas que se inspiravam na temporalidade e na espacialidade introduzidos pelos cinemas novos da época, estabelece relações com o universo extradiegético de então. $\mathrm{O}$ texto busca situar as maneiras pelas quais no folhetim eletrônico essas convenções estéticas captam e expressam transformações em curso na paisagem urbana, social, de relações de gênero na nascente sociedade de consumo da São Paulo do final dos anos 60.

Palavras-chave

Telenovela, gravação, paisagem urbana, relações de gênero, digitalização.

Abstract Based on the analysis of the seven episodes of Beto Rockfeller, a telenovela produced and aired by São Paulo pioneer TUPI station in 1968-9, and written by theater writer Braulio Pedroso, which are part of the TUPI archive and which have been recently restaured as part of the Fapesp financed project of digitalization of the TUPI archive by Cinemateca Brasileira, this paper explores the potentialities of TV archives to open new venues of understanding of Brazilian recent history, especially of the connections between telenovelas and shifting notions about the urban space, gender and social relations. The paper explores specific connections between diegetic and extra diegetic references to specific urban and social landscapes and the emerging consumerism of the time.

Keywords Telenovela, recording, urban space, genre relation, digitalization. 
De todas estas novelas, a que mais me marcou foi Beto Rockfeller. Esta novela mudou muita coisa dentro de nós. Ela retratou muitas coisas que queríamos fazer. Naquela época não havia muita liberdade (...). Nós assistíamos a liberação de Beto. Aquilo foi demais. Nunca havíamos visto nada igual. E depois daquela novela, eu quase não vi mais transformação de coisa alguma. (Nando, médico morador de condomínio no Morumbi, São Paulo)

Uma imagem de Marlon Brando em O Selvagem (The Wild One, 1953) em primeiro plano, de frente para a câmera, usando um boné e um casaco de couro preto, montado em uma motocicleta, serve de fundo à sequência de créditos do capítulo 72 da novela Beto Rockfeller. A mesma imagem encerrara o capítulo anterior do folhetim eletrônico. O pôster faz parte do cenário da novela, decora com destaque a parede do pequeno quarto do protagonista que dá título à série. Posicionado em frente à cama de Beto, Marlon Brando no papel antológico do jovem líder de um bando de motociclistas olha para ele e para o público como que abençoando a corrida de motocicleta que mobilizara a trama nos últimos capítulos e que ocupa o capítulo que se inicia e o próximo.

A novela alude ao drama de gangues rivais, que se batem em corridas coletivas, de que fala o filme, um grande sucesso dos anos 1950. Mas na novela a história é diferente. No Brasil dos anos 1960, a motocicleta era símbolo de liberdade jovem, mas era esporte de playboy, no qual Lavito, jovem de classe média alta, autor do desafio ao rival, milionário impostor, é mestre. Com sua turma de amigos motociclistas e respectivas namoradas na garupa, o personagem 
3. Para referências sobre Beto Rockfeller, ver Gianfrancesco, Mauro e Neiva, Eurico. De Noite tem...Um show de Teledramaturgia na TV Pioneira (São Paulo: Giz Editorial, 2007). P. 211-214. Ver também Artur da Távola, A telenovela Brasileira: História e conteúdo (Rio de Janeiro: Editora Globo, 1996). P. 93-94. E Ismael Fernandes, Memória da telenovela brasileira (São Paulo: Brasiliense, 1997). 115-117. ocupa as novas avenidas de uma cidade em expansão. Já o "bicão" de origem humilde não possui a mesma intimidade com o veículo. Embora senhor de si, sedutor inveterado, Beto precisa se preparar para o duelo, o que faz com uma moto emprestada e com ajuda dos conhecimentos técnicos de seu amigo Vitório (Plínio Marcos) que trabalha como mecânico na oficina de Seu Domingos, uma das personagens inventadas e interpretadas por Lima Duarte, que além de dirigir a novela, encarna alguns personagens secundários, porém marcantes, entre os quais esse misterioso dono de oficina. Vitório chega a dialogar com Marlon Brando no cartaz, um improviso em que o personagem demonstra sua camaradagem com o líder das motocicletas que contagiou partes do mundo atendidas pelo cinema industrial americano nos anos 1950.

Beto Rockfeller teve 298 capítulos de cerca de 30 minutos, exibidos durante 13 meses, de 4 de novembro de 1968 a 28 de novembro de 1969 na Tupi de São Paulo e na TV Rio. A novela terminou às vésperas do AI-5. A repercussão de público e crítica trouxe alento à emissora pioneira, que nos anos 1960 enfrentou a concorrência, primeiro da Excelsior, que lançou a novela diária, e depois da Globo, que montou o primeiro departamento de dramaturgia. Beto Rockfeller ficou registrada na imprensa escrita especializada, mas também nos principais órgãos de imprensa diária como Jornal do Brasil e Estado de S. Paulo e na maior revista semanal, Veja, bem como na literatura especializada ${ }^{3}$ como a novela que renovou o gênero ao introduzir gravações externas, diálogos coloquiais, um protagonista anti-herói, em um drama contemporâneo. A novela é também reconhecida como a primeira a lançar mão do merchandising e como precursora das novelas das oito horas da noite, com as quais a Rede Globo se consolidou na posição de emissora mais assistida logo a seguir, no início dos anos 1970. Essas considerações, no entanto, não esgotam o assunto. A visualização do material da novela permite ir além, notando as maneiras pelas quais a novela conectou universos eruditos e da indústria cultural em torno de um repertório de liberalização dos costumes associada à ascensão social e ao consumo.

No depoimento que serve de epígrafe a esse texto, um médico e morador de um condomínio de luxo no bairro do Morumbi, oferece um relato sugestivo sobre a conexão entre essa novela em particular, Beto Rockfeller, e um certo desejo de liberdade que ele identifica com sua época de estudante. Nando hoje é um homem de classe média 
alta, bem sucedido, casado e pai de três filhos. Seu depoimento foi dado no contexto de uma pesquisa de recepção sobre novelas e especificamente sobre a novela que ia ao ar na época, O Rei do Gado. Nando não hesitou em descrever a si mesmo, ainda que no passado, como um leal espectador de telenovelas. A referência faz menção a um tempo longínquo, quando vivia em uma pensão, recém chegado a São Paulo, vindo de sua pequena cidade natal, no Norte do estado do Paraná. O ano era 1968 e o então estudante tinha 18 anos.

A menção à novela por parte de um médico e a maneira pela qual ele vincula o folhetim com anseios de liberalização que marcaram aquela época e aquele ano em particular, em diversas cidades do mundo inspira esse ensaio sobre as relações entre Beto Rockfeller, modernidade e consumo. A visualização dos seis capítulos que sobraram no acervo da TV TUPI (Capítulos 34, 35, 71, 72, 73 e um sem numeração) especialmente dos três capítulos na casa dos setenta, permite imaginar conexões entre essa novela, o desenvolvimento do mercado consumidor nos grandes centros urbanos e a indústria cultural. No caso dessa novela, anterior à era de domínio da Globo, há pontes com a ativa cena teatral e universitária paulistana dos anos 1960, com a nascente, porém ainda informal, publicidade e com processos de transformação urbana em curso na cidade de São Paulo.

$\mathrm{Na}$ linha do que Miriam Hansen (1999) define como modernismo vernacular, (ou talvez o termo coloquial ofereça melhor tradução), é possível associar essa novela a uma certa pedagogia do comportamento, da moda e do consumo, como o cinema industrial, especialmente de itens que a novela apresenta de maneira associada aos ricos liberais, como cigarro, uísque, moda feminina, e meios de transporte, de maneira análoga ao primeiro cinema, associam a televisão à velocidade e à liberdade de deslocamento no tempo e no espaço.

Não há, no entanto, no caso da novela uma gramática de montagem que se assemelhe à montagem do cinema industrial. Feita de maneira bastante improvisada, a novela contém longas sequências espontâneas, colocadas no ar quase que diretamente depois de gravadas. Há assim muitos tempos mortos, especialmente em sequências gravadas em locações externas, como longos pesadelos que se aproximam do surreal ou a própria corrida de motos, clímax de todo um segmento da história. Talvez seja produtivo pensar a novela como um espaço onde as esferas artístico-teatral e 
da indústria cultural interagem, provocando uma espécie de curtocircuito que reverbera de maneira definidora na ficção televisiva dos anos 1970 e 1980.

Beto se faz passar por um milionário com o objetivo de ganhar a confiança e se casar com uma moça rica. Personagem cativante, engraçado, carinhoso e descontraído, sem papas na língua ele afirma, sem culpa, seus objetivos de moral duvidosa. Beto se define como "pra frente", veste-se de acordo com a moda da Rua Augusta, que na época anterior aos shopping centers era o maior centro de compras caras, e se comporta também de acordo com o que imagina seja um mundo do "vale tudo". O discurso de Beto lembra o comportamento de Maria de Fátima (Glória Pires), personagem criada por Gilberto Braga, 20 anos depois. Mas Beto é bem humorado, sedutor, em certo sentido ingênuo, quando comparado à sua descendente global.

O consumo de roupas, bebidas, cigarros, carros, telefones, motos apresenta-se como diferencial entre a vida das personagens abastadas que vivem em torno da rua Augusta, especialmente jovens e mulheres, e os trabalhadores que vivem a apenas alguns quarteirões dali, nas imediações da rua Teodoro Sampaio, onde Beto mora com sua família e trabalha. Em seu percurso fantasioso, Beto envolve-se com a candidata a futura sogra, Maitê (Maria Della Costa), mãe de sua namorada Lu (Débora Duarte) e casada com Otávio (Walter Foster), que por sua vez se envolve com sua secretária Neide (Irene Ravache), irmã de Beto. O potencial de desestruturação familiar da história é atenuado aparentemente por pressão da censura, já atuante à época. De maneira implícita, a novela aludia ao esgotamento do casamento burguês e à legitimidade da liberdade sexual, ideias afirmadas de maneira cada vez explícita e provocativa ao longo das novelas das próximas décadas.

Seu objetivo seria parcialmente cumprido (o futuro sogro oferecelhe uma proposta de contrato de casamento com separação total de bens), se o personagem não recuasse, arrependido de sua falta de escrúpulos e disposto a abandonar as mulheres com quem se envolveu para buscar um novo começo fora de São Paulo. Malgrado o final melancólico de Beto, sua irmã Neide se desenvolve de maneira mais positiva. A personagem passa pela transformação à qual o espectador em nossa epígrafe se refere e que se expressa na mudança de seu visual, em especial do corte de cabelo, de um convencional corte 
mediano, para um fashion bem curto à la garçonne. A independência de Neide se expressa também em sua decidida ruptura do caso com o patrão e no casamento com um jornalista, profissão associada aos meios de comunicação, ao polo moderno. No final, embora a ordem de apresentação do elenco e algumas notícias da época do lançamento tenham sugerido que o principal envolvimento amoroso de Beto seria Maitê, personagem interpretada por Maria Della Costa, talvez movidos pelas limitações impostas pela censura naqueles tempos quentes, o casal burguês se reconcilia confirmando o tom convencional dos personagens mais velhos formado por conhecidos atores experientes e mais compostos.

Vejamos como se dá o curto-circuito de repertórios e como ele potencializa a novela a extrapolar os estreitos limites a ela reservados no interior das normas da indústria cultural. Beto Rockfeller adota bandeiras libertárias da contracultura, com as quais os atores sintonizados com a densa cena teatral de então estavam familiarizados, num dos gêneros mais comerciais e convencionais da televisão. A censura controlava os discursos relacionados a comportamentos, que ficaram, no entanto, bastante implícitos na postura corporal e na entonação de atores que improvisavam e se divertiam em torno de seu próprio repertório.

Embora a TV tenha sido inaugurada no Brasil em 1950, até 1963, quando o videotape passou a ser usado na programação diária, não havia circulação nacional de programas. Tal tecnologia permitiu que lugares diferentes vissem os mesmos programas, mas com atrasos que variavam de acordo com o tempo que a fita demorava a chegar. Beto Rockfeller foi ao ar em um período em que a televisão ainda não alcançava todos os estados brasileiros, e no interior de cada estado, as regiões que recebiam sinal televisivo eram limitadas. Em um país de cerca de 90 milhões de habitantes, apenas cerca de nove milhões

4. Para dados sobre a evolução do alcance da televisão no território brasileiro e do crescimento do número de domicílios com

TV ver Esther Hamburger,

"Diluindo fronteiras: as novelas no cotidiano," in História da vida privada, vol 4, ed. Lilia Schwarcz (São Paulo: Cia das Letras, 1998). tinham acesso à televisão ${ }^{4}$. Somente a partir do final de 1969 a transmissão em rede nacional se tornou possível.

Numa época em que muitas novelas estavam sendo adaptadas de roteiros mexicanos, cubanos ou argentinos, Beto Rockfeller legitimou-se como uma novela brasileira e contemporânea. A novela de Bráulio Pedroso foi ao ar em um período em que o gênero se tornava estratégico na programação televisiva. O surgimento de novas emissoras acirrava a concorrência no campo da televisão e a novela 
se afirmou como produto através do qual as emissoras competem, posição que hoje, 45 anos depois, ainda ocupa.

A Excelsior, inaugurada em 1960 e a Globo, em 1965 ameaçaram o predomínio da Tupi de São Paulo, que muitas vezes trabalhava com a TV Rio de Walter Clark, em detrimento de sua própria afiliada, a Tupi do Rio de Janeiro. As duas novas emissoras investiram na popularização e ampliação do público televisivo recorrendo ao amplo repertório de produções de novela acumulado em um circuito latino-americano.

Em 1963 a Excelsior introduziu a novela diária, 2-5499 Ocupado, baseada em um original argentino e interpretado por Glória Menezes e Tarcísio Meira, o casal que marcaria a consolidação da versão brasileira do gênero na década seguinte na Globo. O título da novela escolhida pela Excelsior para inaugurar seu horário de novela diária sugere que Beto Rockfeller não inventou a novela situada no tempo contemporâneo e que se estrutura a partir da referência às tecnologias de comunicação. A personagem de Glória Menezes era uma telefonista em um país em que até o final do século XX o telefone permaneceria disponível apenas a parcelas muito restritas da população, embora intensamente utilizado como recurso narrativo na televisão.

A Tupi reage com a adaptação de O Direito de Nascer, de dezembro de 1964 a junho de 1965, em associação com a TV Rio. O conhecido título de autoria do cubano Félix Caignet foi escrito em 1946 para a Rádio Havana e repetidamente adaptado para o rádio e para a televisão na América Latina. O texto mobiliza marcadores sociais da diferença na chave do melodrama, mostrando de maneira crítica os maus tratos impingidos por um patriarca à sua filha, que contra a vontade do pai dá à luz a um neto ilegítimo. Perseguido pelo avô materno branco e rico, a criança sobrevive graças à mobilização da mãe biológica e principalmente da mãe de criação. A primeira entrega o filho aos cuidados da segunda: Mãe Dolores, como ficou conhecida a personagem da ama de leite negra que cria o menino. Adulto, o jovem ascende social e profissionalmente e se dedica a buscar o pai. Em solução conciliatória, ele não só perdoa, como aplica seus conhecimentos de medicina para salvar o avô. A novela se passa na Cuba do início do século XX, mas seu sucesso pode ser atribuído à tematização de preconceitos em vigor em diversos países 
da região, em uma trama com personagens e oposições esquemáticas entre bons e maus.

O último capítulo da novela cubana foi transmitido ao vivo, primeiro em São Paulo e depois no Rio, a partir de concentrações populares em estádios de futebol. Apenas um ano após a exibição da primeira novela diária pela Excelsior, o gênero afirmava parâmetros que escapavam à cultura erudita em ambientes que extrapolavam o espaço doméstico da casa. Parte da equipe que realizou O Direito de Nascer foi escalada três anos depois para fazer Beto Rockfeller, embora o tom das duas produções fosse muito diferente. Lima Duarte dirigiu os primeiros capítulos da novela cubana. Luiz Gustavo estava no elenco de O Direito de Nascer em papel secundário. Walter Foster, o consagrado ator de radionovelas, interpretara Cagnet no rádio.

A Globo apostou em novelas desde o início de suas operações. A nova emissora foi a primeira a estabelecer um departamento interno de teledramaturgia e contratou outra cubana, a exilada Glória Magadan, para dirigi-lo. Magadan já atuava na realização de novelas, mas a partir de agências de publicidade, como a Lintas ou a Colgate Palmolive, muitas vezes encarregadas não só do patrocínio como da produção do gênero que era considerado a soap opera da América Latina. Magadan trouxe para a emissora seu estilo, o de produzir histórias rocambolescas que se passavam em terras e/ou tempos distantes. Magadan orientava roteiristas que trabalhavam sobre a sua direção a evitar referências a eventos que replicassem tensões sociais. Novelas sob sua orientação buscavam o registro fantasioso como $\mathrm{O}$ Sheik de Agadir (Glória Magadan, 1966-1967), A Rosa Rebelde (Janete Clair, 1969), ou Sangue e Areia (Janete Clair, 1967-1968, título que possui duas adaptações cinematográficas hollywoodianas, a primeira com Rudolph Valentino). Os figurinos são de época e os cenários construídos em estúdio.

É possível pensar que as convenções que marcam o que ficou conhecido como a novela brasileira estabeleceram-se como reação a essas investidas latino-americanas. Pressionada pela concorrência, a Tupi propôs algo inovador e nacional. Em sintonia com o clima de movimentação social, Cassiano Gabus Mendes, diretor de programação da emissora de São Paulo, formulou o conceito de Beto Rockfeller, que seria gravada de preferência nas ruas, fora do estúdio, em muitas locações externas e com diálogos coloquiais, 
figurinos e trama contemporâneos. Agindo como produtor, o filho do radialista Otávio Gabus Mendes, que depois da falência da Tupi se consagraria como autor de novelas na Rede Globo, onde seus dois filhos, Cássio e Tato Gabus Mendes se afirmaram como atores, montou uma equipe capaz de dar vida ao argumento inspirado na cena noturna paulistana, e que seria estrelado por seu cunhado Luiz Gustavo. Lima Duarte, que como já foi dito, dirigira os primeiros capítulos de O Direito de Nascer, seria o diretor. Bráulio Pedroso, autor de teatro, escreveria a história do "bicão". A escalação do roteirista e de atores que participavam da aquecida e vanguardista cena do teatro paulistano trouxe elementos novos a um dos produtos mais industriais da televisão. A equipe aliava o capital cultural do conhecido autor, a irreverência de um ator como Plínio Marcos (à altura já conhecido por peças como Navalha na Carne), o prestígio da consagrada Maria Della Costa, a experiência de Marília Pêra, a juventude de promissoras atrizes de teatro como Irene Ravache e Bete Mendes (esta também estudante de Ciências Sociais na Universidade de São Paulo) e o conhecimento e a experiência no meio televisivo de Lima Duarte, ainda não consagrado como ator de televisão (o que ocorreria na Globo com a personagem Zeca Diabo em O Bem Amado de Dias Gomes, 1973). A sensação da equipe de estar em casa completava-se com relações familiares e conjugais. Débora Duarte, por exemplo, é enteada de Lima Duarte.

A Tupi de São Paulo investe em Beto Rockfeller apostando na novidade de um produto atual e provocativo que oferecia o talento de artistas de teatro ao grande público em uma história reconhecida já na imprensa da época como marco na teledramaturgia. Segundo matéria publicada pelo Jornal do Brasil no dia seguinte ao final da novela na cidade de São Paulo (no Rio de Janeiro, segundo a mesma notícia, a novela ainda iria ao ar em janeiro e fevereiro de 1970), os índices de audiência conquistados pela "primeira experiência brasileira da novelaverdade" foram considerados bons à época em que a audiência oscilava entre as seis emissoras existentes sem demonstrar um favorecimento estável ou uma maioria absoluta, como viria a acontecer depois, nos anos 1970, com a ascensão da Rede Globo. O texto do então importante jornal diário informa que os índices fornecidos pelo Ibope oscilaram entre o máximo de 39\% e o mínimo de $20 \% 5$.

4. "O fenômeno Beto Rockefeller," Jornal do Brasil, 29 de novembro

Além dos índices de audiência e da longa matéria no Jornal do 1969. Brasil, a novela repercutiu em outros órgãos de imprensa escrita, 
como O Estado de S. Paulo e Veja, extrapolando o campo da imprensa especializada em televisão. As matérias nos jornais da grande imprensa surgiram no decorrer ou no final da novela reverberando as novidades.

Já o lançamento da novela foi anunciado, como de costume, em revistas como O Sétimo Céu, especializada em televisão e fotonovela, e InTerValo, guia de televisão, ambas dirigidas principalmente ao público feminino. Embora segmentadas, essas revistas destacam a presença de profissionais do teatro na nova novela da Tupi, indicando que a própria emissora divulgou essa presença erudita como um diferencial do título. O Sétimo Céu dedicou várias páginas a apresentar os personagens da trama a partir de seus intérpretes. Uma foto grande de Luiz Gustavo abre a matéria em página dedicada a descrever Beto como um "sujeito bastante ambicioso que para viver na alta sociedade não hesita em dar golpes em todo mundo". Significativamente, a revista segue com a apresentação do casal bem composto formado pela personagem de Maria Della Costa em sua primeira participação televisiva e seu marido Otávio, interpretado por Walter Foster, o consagrado galã de radionovelas. Talvez índice de maior liberalidade, InTerValo destaca a presença da jovem atriz Irene Ravache como par romântico de Walter Foster, apostando no desenlace do caso de amor entre o patrão e a secretária. O guia de televisão destaca também a presença de Plínio Marcos, um autor e ator de teatro que teria agora, na televisão, a possibilidade de encontrar o grande público. A anunciada interpenetração entre o teatro e a televisão produziria novidades que repercutiriam na grande imprensa no decorrer da trama, alimentando a experiência e prolongando a novela, a ponto de esgotar a equipe. Lima Duarte e Bráulio Pedroso teriam se afastado, o que ajuda a entender o final melancólico da trama. Luiz Gustavo tirou 30 dias de férias, durante a novela, o que obrigou seu personagem a fazer uma longa viagem. A repercussão na imprensa e o estilo contemporâneo da novela permitiu que a Tupi de São Paulo recuperasse momentaneamente a posição de emissora de ponta, embora Excelsior e Globo se apresentassem como mais jovens e com design mais contemporâneo.

Voltando à sequência de abertura do capítulo 72, em cartelas transparentes sucessivas, com letras brancas sobrepostas ao rosto de Marlon Brando, as Emissoras Associadas apresentam a seleção de atores, em uma ordem que salienta o diferencial apontado na 
imprensa. O nome de Maria Della Costa é o primeiro, indicando um protagonismo que os capítulos disponíveis não permitem entrever. Sua personagem burguesa entediada, de voz empostada e movimentação corporal dura, seguia as convenções anteriores. A seguir, Luiz Gustavo, promovido a galã, talvez viesse flertar com a estrela. A história era de Beto. Muito à vontade na pele do personagem, Luiz Gustavo improvisou longos bifes nos quais se definia como "pra-frente", um rótulo de significados múltiplos, que incluem o desejo de liberdade individual, para além de estruturas sociais e políticas, mas que incluem também, com igual ou maior força, a vontade de ascensão social. Beto é malandro; para ele, a desejada mobilidade não viria do esforço do trabalho ou do estudo, mas de uma disposição a não se acomodar e da coragem de se expor ao risco de conquistar uma noiva rica, mesmo que para isso tivesse que enganá-la sobre sua verdadeira situação social.

A seguir, vem o título: Beto "Rockfeller". O letreiro da novela ironicamente traz o sobrenome do personagem protagonista entre aspas e com erro de grafia, talvez para que não se confunda com a evidente inspiração no nome de Nelson Rockefeller, o neto do fundador da Standard Oil, político norte-americano, amigo das artes e conhecido emissário dos Estados Unidos junto aos países da América Latina.

Após os destaques, um genérico Participam introduz inicialmente nomes que aparecem sozinhos, e o primeiro é o de Walter Foster, um ator então em declínio. Logo os créditos do restante do elenco seguem em cartelas com dois ou três nomes. A câmera se desloca ligeiramente da imagem do rosto do ídolo do cinema americano para a moto, farol, guidão... até chegar na imagem dos irmãos Neide (Irene Ravache) - já em seu figurino moderno - e Beto, que repousa em seu colo. Durante o movimento de câmera para a direita, os créditos de sonoplastia, montagem, produção e finalmente as cartelas: Escreveu Bráulio Pedroso, Dirigiu Lima Duarte.

O capítulo foi ao ar em fevereiro de 1969 e a trama encontrase em momento crítico: o protagonista malandro vê-se obrigado a disputar uma corrida de moto, uma espécie de duelo contemporâneo. Desafiado pelo rival rico, o vendedor de sapatos da rua Teodoro Sampaio terá de provar que domina as artes da velocidade motorizada. Os três capítulos sucessivos, 71, 72 e 73 giram em torno da corrida 
que possivelmente foi assunto de capítulos anteriores. No capítulo 71, que se inicia com uma insólita conversa entre seu Domingos, o dono da oficina mecânica, figura misteriosa, de fala italianada, seu empregado Vitório, amigo fiel de Beto, interpretado por Plínio Marcos, e o herói "sem caráter", que pede ajuda do amigo para treinar para a corrida. Seu Domingos aparece de pé em cima de um telhado, em contra plongée e contraluz. Lá do alto esbraveja contra Beto e sua má influência sobre Vitório. Seu Domingos é um dos personagens interpretados por Lima Duarte e seu rosto nunca aparece, o que dá ao personagem uma aura de mistério, que contribui com a trama.

Os dez minutos finais do capítulo são dedicados a um pesadelo de Beto que confere ao capítulo um tom surreal. A imagem de duas motos em posição de largada, com Beto ligeiramente atrás. Seu concorrente, muito melhor aparelhado, está vestido com roupa de mergulho com direito a balão de oxigênio. Ambos estão em uma laje que logo se revelará o teto de um prédio de onde se vê a cidade. A moto de Beto se transforma em um desajeitado e pequeno triciclo, pequeno para o personagem de Luiz Gustavo, que no entanto se desloca montado no brinquedo infantil. Em seu sonho, Beto se sente observado fixamente por Maitê, personagem de Maria Della Costa, que seduz o personagem e cujo olhar escrutinador no sonho, incomoda o protagonista. Beto cai do triciclo. Aflito, estende a mão em busca de ajuda, mas ninguém comparece. De repente, um desfile de amigos ou familiares vestidos em trajes carnavalescos. Beto mal se levanta. É enforcado pelo rival em seu próprio quarto sob o olhar de Marlon Brando. Por último uma imagem trucada de uma moto suspensa no ar se impõe sobre o corpo deitado de Beto. A moto flutuando em paralelo ao corpo do ator ao mesmo tempo ameaça esmaga-lo e se insinua.

Embora a pequena amostra de capítulos que restaram sugira que a novela foi principalmente gravada em estúdio, há uma diversidade de referências a pontos conhecidos da cidade de São Paulo, para além da oposição inicial e estrutural entre as ruas Augusta e Teodoro Sampaio, duas vias paralelas de acesso ao espigão da Paulista que ficam cerca de um quilometro uma da outra, mas que um dia, antes da existência dos Shopping Centers, simbolizavam níveis de poder aquisitivo diferentes. Há referência ao Clube Harmonia, tradicional reduto nos Jardins, como local frequentado pelas madames da história. Já os empresários, como a personagem de Walter Foster, 
costumam almoçar no Automóvel Clube, restaurante do centro da cidade, fechado recentemente. Entre as habilidades de Beto está o domínio dessa geografia social. É dele a afirmação de que seu pai é dono de terrenos no bairro chique do Morumbi, com vista para o Jockey Clube. É interessante observar que o entrevistado da epígrafe desse texto, à época da entrevista, havia subido socialmente, estava realizado como médico, e morava justamente no Morumbi.

Beto refere-se a esses repertórios da geografia social da cidade como se fosse um insider. Esse repertório inclui, como já foi dito, termos em inglês e conhecimento de nomes e personas de atores hollywoodianos. A referência ao cinema não se esgota na interlocução com Marlon Brando que observa os movimentos amadorísticos de seu fã tropical. As falas de Beto estão recheadas de referências cinematográficas. Sua inspiração sobre esse mundo livre no qual quer ser admitido vem de vasto repertório de filmes e atores glamorosos de Hollywood. É o universo do espetáculo que ele almeja para si, para sua irmã e amigos mais próximos. O mundo do personagem de Marlon Brando realiza-se a poucas quadras de casa na rua Augusta povoada pela turma de seus novos amigos.

Nos capítulos 72 e 73, durante cerca de 45 minutos a corrida de motos serve de pretexto para gravações externas. A corrida é precedida por uma série de três panorâmicas que descrevem o ambiente urbano, casas grandes e prédios, que hoje parecem discretos. É possível reconhecer que a paisagem é a do bairro do Sumaré, ao redor do prédio da emissora. As panorâmicas desembocam em avenida larga de pista dupla ainda em obras. A paisagem de fundo de vale não é vazia de construções. Vemos operários da construção civil que trabalham na ilha que separa as duas pistas da avenida. Vemos carros, fuscas e outros, em meio aos quais os motoqueiros desfilam seus veículos mais ágeis. A corrida é precedida e sucedida por cenas em que cerca de quinze motocicletas passeiam pela avenida, em movimento circular, graças a um retorno que permite a passagem de uma pista a outra.

Comparadas às atuais motocicletas que dominam as vias paulistanas e muitas metrópoles do mundo - instrumento de trabalho de ainda jovens motoqueiros, mensageiros, que agressivamente se imiscuem entre os carros no trânsito congestionado - as imagens da novela parecem lentas e as motos, desajeitadas. Não há capacetes 
e, embora haja competição e queda, o clima é de gincana. As namoradas vão na garupa dos leves veículos glamorosos de passeio de seus pares. Na comemoração da vitória de Beto, no ambiente luxuoso da casa de Lu (Débora Duarte), onde a mãe e sua amiga (Marília Pera) aguardam ansiosamente, vemos que elas fumam e se servem de whisky. Suas roupas de moda sinalizam a atualidade do figurino.

Talvez a posição do autor da fala reproduzida na epígrafe, o jovem do interior, recém-chegado à capital, em busca de formação, independência e inserção em um mundo que prometia ser menos provinciano, possa ser percebida como análoga à posição do personagem Beto, um estranho no mundo de seus novos amigos da rua Augusta, onde estavam situadas à época as melhores lojas e boutiques da cidade. O movimento de Beto, na tentativa de dominar os repertórios simbólicos necessários a ser plenamente incluído nos círculos da elite entediada e fútil, sensibiliza a imaginação de jovens vindos das mais diversas partes do país em busca de um estilo prafrente, livre de constrangimentos da vida provinciana do interior, para escrever sua própria história. O forte sotaque italiano que caracteriza a fala dos moradores do bairro de Pinheiros é sintomático dessa marca de origem da qual o personagem sonha se livrar.

Moço de um bairro de classe trabalhadora, Beto é um forasteiro - quase um caipira - que entra em contato com um grupo de jovens que se vestem, falam e fazem coisas que "estão na moda" como dirigir moto e fumar, e não trabalham nem estudam. Beto se revela apto a usar de conhecimentos, gírias e até termos em inglês, aprendidos provavelmente no cinema, já que o repertório cinematográfico do personagem é amplo, a partir do já citado herói da rebeldia motoqueira dos anos 1950. Uma rebeldia que se volta contra as regras que excluem a classe trabalhadora da vida boa, mas entediada que os ricos levam; uma rebeldia que não necessariamente questiona discriminações. Beto não tem dificuldade em apreender um repertório difundido pela mídia e que lhe permitiria abandonar códigos tradicionais de solidariedade familiar, de classe, de bairro, de origem imigrante.

Em entrevista por ocasião dos 40 anos da novela, Lima Duarte reconhece que a equipe escolheu trabalhar com elenco composto de atores "próximos". Luiz Gustavo era cunhado do diretor da emissora Cassiano Gabus Mendes, filho do radialista Otávio Gabus Mendes 
6. Para o funcionamento "vertical" da indústria de cinema norte-americana que inspira a indústria de televisão brasileira ver Thomas Schatz, $\mathrm{O}$ Gênio do Sistema (São Paulo: Companhia das Letras, 1991).

7. Ver entrevista de Lima Duarte em (http://www.estadao.com.br/noticias/ suplementos, beto-rockfeller-foi-umruido-na-teledramaturgia,278466,0. htm 18/11/2008) e diretor da TV Tupi, desde a inauguração da emissora. Sua atuação na criação da novela é a de um produtor no sentido clássico do termo ${ }^{6}$. É dele a ideia de contar a história de um "bicão" charmoso e sedutor que penetra um universo de classe média alta em busca de um bom casamento. É dele a ideia de abandonar a música clássica, que caracterizou as trilhas sonoras de novelas até então, para propor o uso de músicas populares, escolhidas, segundo depoimento de Lima Duarte, entre o repertório de álbuns tocados em sua boate. As músicas temas mencionadas ajudam a caracterizar as personagens aludindo a diversos estilos e línguas estrangeiras. O tom romântico italiano de Dio, Come ti Amo (Domenico Modugno) ou Comme Femme (Salvatore Adamo), ajudam a caracterizar a melancolia desejosa dos personagens de Ana Rosa e Bete Mendes, duas apaixonadas pelo herói. Mais propositiva, a personagem de Irene Ravache, que se "transforma" durante a novela, tem como tema a música Here, There and Everywhere dos Beatles, que chegava ao Brasil nessa trilha?

Embora os capítulos existentes não tragam nenhum exemplo, é conhecido o fato de que o ator Luiz Gustavo, em acordo direto com anunciante, fazia merchandising de Engov, remédio para enjoo e ressaca. Esse é o primeiro caso que se tem registro de propaganda no interior de novelas, prática que se institucionalizaria mais tarde. Em entrevistas o ator se justifica dizendo que a Tupi na época atrasava salários e ele precisava do dinheiro para sobreviver. A prática era possível dada a informalidade que regia a relação entre anunciantes e a emissora. A marca do improviso que dominava as gravações de Beto Rockfeller, e que pode ser facilmente percebida nos capítulos disponíveis, também facilitava essa propaganda de Engov. Lima Duarte, na já citada entrevista que comemorou os 40 anos dessa novela, conta que os atores sistematicamente contribuíam com "cacos". As falas previstas no roteiro eram alteradas, conforme sugestões preparadas ou improvisadas na hora. A criação de personagens interpretados pelo próprio diretor confirma a abertura da novela à modificação do roteiro. Esses improvisos pareciam animar as gravações e satisfazer a equipe. $\mathrm{O}$ Engov entrou na mesma chave e se integrou. O remédio combinava com a irreverência de Beto e confirma as relações de intimidade entre novelas que se passam no tempo contemporâneo e em espaços conhecidos, e o anúncio de produtos que podem ser consumidos por espectadores e personagens. 
8. Ver especialmente Theodor

W Adorno, "Culture industry reconsidered," New German Critique n. 6 ( 1975).
9. É possível que Véu de Noiva tenha se inspirado, ao menos em parte, em Vestido de Noiva, peça de Nelson Rodrigues conhecida como a primeira peça de dramaturgia brasileira moderna. Aparentemente além da semelhança no título, ambas compartilham alguns traços de roteiro. A relação dessa novela com a peça de Nelson Rodrigues merece future investigação.
Esse tipo de merchandising, tal como a exibição de moda, cigarro, uísque, telefones ou motocicletas, constituem uma via de acesso dos espectadores ao universo dos personagens. É como se, ao adotar acessórios sugeridos pelos personagens, os espectadores compartilhassem seu posicionamento no mundo. As relações de contiguidade, de identificação, de empatia, estimuladas pela lógica da indústria cultural e descritas de maneira visionária por Adorno ${ }^{8}$ promovem ideias através de coisas. O mundo moderno e descontraído no qual Beto penetra estaria disponível para quem quisesse ouvir as músicas que compunham a trilha sonora, adotar modelitos, fumar, beber, curtir a velocidade com vento na cara (e sem capacete). O ambiente urbano e impessoal da cidade grande é o espaço privilegiado onde esses ícones de modernidade estariam acessíveis também a quem vem de fora, ou de baixo.

Em 1969, coincidindo com o início da rede nacional, a Globo demite Glória Magadan e promove Daniel Filho à direção do departamento de Dramaturgia. No comando, o ator e diretor com experiência na TV e no cinema inicia a transformação que estabeleceria uma série de convenções que consolidariam a indústria de televisão no Brasil com a novela em sua base. As modificações se inspiram no modelo introduzido por Beto Rockfeller, mas com uma organização de produção mais próxima do modelo industrial. Depois de Magadan, as novelas do horário principal passaram a se situar no Brasil contemporâneo - portanto sucessivamente atualizado. Muitas vezes há uma introdução que se passa no exterior, um recurso que reforça a proximidade do espaço principal da novela. Véu de Noiva (1969) de Janete Clair é o primeiro título de uma longa série. A novela, dirigida por Daniel Filho inicia uma convenção que depois se afirmaria, que é a de fazer referência a símbolos e atividades que mobilizam a imaginação nacional no caso a Fórmula 1, esporte que o protagonista, interpretado por Claudio Marzo, aludia ao esporte em que o corredor Emerson Fittipaldi se consagrava?.

Novelas difundiram modelos de relacionamento familiar divergentes do patriarcalismo ainda em vigor nos anos 1970, 80 e 90 no nordeste brasileiro, e em outras partes do mundo para as quais foram exportadas, como Portugal, Cuba ou China. Famílias com poucos filhos, envolvimentos românticos fluídos e múltiplos, mulheres que trabalham fora, ou que se separam em busca de 
realização pessoal e sexual, constituem base recorrente de conflitos que alimentam tramas recorrentes.

Beto Rockfeller parece ocupar posição intermediária no que se refere a essas questões. Durante os 13 meses em que a novela esteve no ar ela insinuou a liberdade sexual entre casais de sexos diferentes, mas também de idade e classe social diferente. O final da novela ainda frustra essas movimentações. As personagens femininas parecem tímidas quando comparadas a suas sucessoras dos anos 1980. Mas estava lá em germe a busca das novas gerações por realização profissional, além da sentimental.

Beto "Rockfeller" quando vista em comparação com novelas que vieram depois e que se basearam em suas inovações, chama a atenção pela ênfase na cidade de São Paulo, seus espaços, bairros e avenidas, e não na nação brasileira, como as novelas dos anos 1970 em especial as da Globo - fariam. A TV de Beto "Rockfeller" ainda era local, e a TUPI perderia a corrida por audiência para a Globo, entre outros motivos, porque sua estrutura não se ajustou à rede nacional com a velocidade que a competição exigia.

No início dos anos 1970 mulheres de novela (PRADO, 1996) urbanas e liberadas fumavam, usavam decotes, bebiam e transavam antes de casar. A tensão estava dada já desde Beto "Rockfeller". Mas é uma tensão que dispensa o discurso político e filosófico que acompanhou a emergência de movimentos sociais, entre os quais o feminista na Europa, nos Estados Unidos e no Brasil. A cidade de São Paulo aparece em Beto "Rockfeller" como cidade privilegiada para a ascensão social e como o lugar da possibilidade de liberdade, anonimato, redução da vigilância familiar e de vizinhos, lugar do consumo, da abundância financeira, do glamour, das roupas de moda e aparelhos eletrônicos. Aqui a cidade não chega a amedrontar ou ameaçar de solidão. O tom era otimista, descontraído, irreverente.

Beto comanda uma festa descontraída na casa de seus novos amigos ricos (e otários) - se comunicando em inglês com Lu (Débora Duarte), sua namorada loira, líder da turma, irreverente e inconsequente: como sua mãe pegou a estrada e seu pai sumiu, a casa está liberada. Os amigos festejam a oportunidade cantando É Proibido Proibir, de Caetano Veloso. O capítulo foi ao ar em 18 de dezembro de 1968. Em setembro daquele mesmo ano, a música cantada por Caetano em apresentação com Os Mutantes na final 
paulistana no TUCA, do III Festival Internacional da Canção, assumido pela Globo, havia sido vaiada pelo público. O cantor baiano respondeu com atuação irreverente e sensual que provocou o auditório. Ao afirmar a música, cantada em coro pelos personagens que participavam da festa na casa de Lu (Débora Duarte), liberada pela ausência momentânea dos pais, a equipe da telenovela se solidarizava com o autor e os intérpretes e se posicionava contra a reação negativa do público do festival.

Em sua descrição do antigo relacionamento com estas séries televisivas, o espectador-médico, morador de um condomínio de luxo nas imediações de Paraisópolis, a segunda maior favela da cidade, hoje uma comunidade, oferece um relato sugestivo sobre a conexão entre uma novela em particular, Beto "Rockfeller" e um certo desejo de expandir os horizontes sociais e morais. O depoimento surpreende pela menção espontânea por parte de um homem de classe média, de uma novela exibida quase trinta anos antes da ocasião da entrevista. Novelas são em geral definidas como femininas, e entre as mulheres, de mulheres pobres. Embora os homens tenham muito boa memória sobre elas, têm dificuldade em admitir que também assistem. Esse médico, não hesitou em descrever a si mesmo como um leal espectador de telenovelas quando veio a São Paulo de sua cidade natal, no estado do Paraná, para cursar a faculdade de medicina.

Ao se referir a um período posterior, quando aparentemente assistia a novelas da Rede Globo ele continua descrevendo sua forte ligação com o gênero, agora caracterizado não mais como libertação, mas como vício:

Lembro-me de quando estava na faculdade, meu Deus, não podia perder um capítulo da novela! Às 7 horas se eu não me sentasse diante do televisor, o dia acabaria mal. Durante o Jornal Nacional eu fazia outra coisa. Estava de fato viciado.

Nos anos 1970, as novelas na Rede Globo, especialmente as novelas do horário das 8 (hoje das 2lhs), estabeleceram-se em torno de temas provocativos associados a comportamento. O apelo "moderno" introduzido por Beto Rockfeller teve continuidade, não somente na já citada Véu de Noiva, mas na sequência de títulos da 
10. Ver Esther Hamburger, O Brasil antenado, a sociedade da novela (Rio de Janeiro: Jorge Zahar Editor, 2005).

11. Ver Heloísa Buarque Almeida,

Muitas mais cousas: telenovela, consumo e gênero (São Paulo: Anpocs/ Edusc, 2003), Tese de doutoramento. faixa horaria, muitos de Janete Clair, que logo se alternaria com Lauro César Muniz na criação de títulos que faziam parte de uma estrutura comercialmente amarrada. A emissora criou em 1971 o Departamento de Pesquisa ${ }^{10}$, responsável por monitorar movimentos quantitativos e qualitativos da audiência. A emissora tratou também de profissionalizar suas relações com anunciantes e agências de publicidade $^{11}$. A audiência de Beto Rockfeller se transferiu, ao menos em parte para as novelas da Rede Globo, assim como parte do elenco e do diretor. Mas apenas cerca de 15 anos depois, em meados dos anos 1980, em plena abertura política, o gênero teria repercussão semelhante à da novela de Bráulio Pedroso, em títulos como Roque Santeiro (Dias Gomes e Agnaldo Silva, 1985), Guerra dos Sexos (Sílvio de Abreu, 1986, no horário das 19 horas) e Vale Tudo (Gilberto Braga, 1988).

A indústria brasileira de televisão consolidou-se baseada em folhetins eletrônicos, que surpreenderiam ao inverter o fluxo unidirecional de mídia, da periferia para outras periferias e para o centro. O projeto de integração nacional que os militares idealizaram como parte de sua doutrina de segurança nacional e no qual a televisão jogava papel estratégico se realizou, mas principalmente calcado não no telejornal e nas adaptações literárias veiculadas na faixa de telenovelas das 18 horas, mas em títulos contemporâneos e provocativos que aludiam às cores nacionais. Dessa forma, de maneira inesperada e não planejada, um gênero classificado como feminino, desvalorizado por seu caráter comercial e seriado, com ramificações na soap opera, de tornou um dos principais espaços de problematização do país.

As novelas brasileiras estão em sintonia com temas caros à modernidade ocidental de maneira peculiar. Nelas temas que se sucederam na história da literatura e das artes ocidentais se sobrepõem. A crítica recorrente ao patriarcalismo se realiza em sucessivos títulos que tematizam relações coronelistas, mas se realiza também na problematização de relações conjugais com a valorização de personagens femininas que logram se realizar pessoal e profissionalmente, e de personagens masculinas cada vez mais esvaziadas. As tensões entre o campo, onde o controle social se exerce de maneira mais direta e pessoal, e a vida mais livre, mas menos solidária, na cidade grande também ecoam temáticas modernas. Temáticas antigas atualizadas no tempo e trazidas para 
o sul do Equador ganham novos significados. No início do século XXI novelas ecoam a insatisfação com a instabilidade que se instalou apesar das melhores condições de vida. A instabilidade das relações pessoais, a corrupção política, as dificuldades da vida cotidiana em metrópoles caóticas, apesar do carro, do avião, do telefone, dos computadores, das máquinas de lavar e de secar, sintonizam decepções com as promessas da modernidade. Beto Rockfeller esteve no início desse transe. 


\section{Referências}

ADORNO, Theodor W. "Culture Industry Reconsidered." New German Critique n. 6 (Fall 1975).

ANTES e depois de Beto.O Estado de São Paulo,16 de novembro de 2008. Lazer e TV, p. 4- 5.

BETO Rockfeller foi um ruído na teledramaturgia. O Estado de São Paulo, 16 de novembro de 2008. Disponível em: <http:// www.estadao.com.br/noticias/suplementos, beto-rockfeller-foium-ruido-na-teledramaturgia,278466,0.htm>. Acesso em 28 jun. 2013.

BETO Rockfeller, o herói sem caráter. Algo de novo nos vídeos? Veja e Leia, no 35,p. 26-32,1969.

COMO vive Beto Roockfeller. Intervalo, n 315, p. 6-9, 1968.

ALMEIDA, Heloísa Buarque. Muitas Mais Cousas: Telenovela, Consumo E Gênero. São Paulo: Anpocs/Edusc, 2003. Tese de doutoramento.

FERNANDES, Ismael. Memória Da Telenovela Brasileira. São Paulo: Brasiliense, 1997.

GIANFRANCESCO, Mauro e NEIVA, Eurico. De Noite Tem...Um Show De Teledramaturgia Na Tv Pioneira. São Paulo: Giz Editorial, 2007.

HAMBURGER, Esther. "Diluindo Fronteiras: As Novelas No Cotidiano." In História Da Vida Privada, Vol 4, edited by Lilia Schwarcz. 439-87. São Paulo: Cia das Letras, 1998.

HAMBURGER, Esther. O Brasil Antenado, a Sociedade Da Novela. Rio de Janeiro: Jorge Zahar Editor, 2005.

HANSEN, Miriam. "The Mass Production of the Senses: Classical Cinema as Vernacular Modernism.” Modernism/ Modernity 6, no. 2 (1999),p. 59-77. 
LIMADuarte: o Quebra Galhos. Intervalo, n 336, p. 3-5, 1969.

MEU irmão Beto Rockefeller. Intervalo, no 323 ,p, 10-13, 1969.

NÃO podia Olhar nada, que tudo era Engov pra mim. O Estado de São Paulo, 16 de novembro de 2008. Disponível em: <http:// www.estadao.com.br/noticias/suplementos,nao-podia-olharnada-que-tudo-era-engov-para-mim,278467,0.htm>_Acesso 28 jun. 2013.

AMOR de Beto está no fim. Intervalo n 333, p. 10-13, 1969.

FENÔMENO Beto Rockefeller. Jornal do Brasil, 29 de novembro 1969.

RENATA vive às custas de Beto". Intervalo no 325, p. 1-3, 1969.

SCHATZ, Thomas. O Gênio Do Sistema. São Paulo: Companhia das Letras, 1991.

TÁVOLA, Artur da. A Telenovela Brasileira: História E Conteúdo. Rio de Janeiro: Editora Globo, 1996. 